Ю.В. Сікірда ${ }^{1}$, Т.Ф. Шмельова ${ }^{2}$, М.В. Касаткін ${ }^{3}$, Ю.І. Тригуб ${ }^{3}$

${ }^{1}$ Льотна академія Національного авіаційного університету, Кропивницький

${ }^{2}$ Національний авіаційний університет, Київ

${ }^{3}$ Харківський національний університет Повітряних Сил ім. І. Кожедуба, Харків

\title{
ОПТИМІЗАЦІЯ СТРАТЕГІЙ СУМІСНОГО ПРИЙНЯТТЯ РІШЕНЬ ОПЕРАТОРАМИ АЕРОНАВІГАЦІЙНОЇ СИСТЕМИ В КОНФЛІКТНИХ СИТУАЦІЯХ
}

У статті представлено проблему визначення оптимальних стратегій сумісного прийняття рішень пілотом та авіадиспетчером як задачу розв'язання “конфлікту” між ними методами теорії ігор. Наведено приклад моделі конфліктної ситуачії “пілот - авіадиспетчер” в особливому випадку в польоті “Відмова та пожежа двигуна на повітряному судні при наборі висоти після зльоту”. Показано, щуо в аварійній ситуації за відсутності зв'язку авіадиспетчера з екіпажем повітряного судна, наявності безпілотних повітряних суден та високій завантаженості зони управління повітряним рухом оптимальною стратегією пілота $\epsilon$ посадка в автоматичному режимі на аеродромі з підготовленою злітно-посадковою смугою, обладнаному радіотехнічними засобами посадки.

Ключові слова: гравціі, критерій Вальда, матрична форма, модель конфлікту, оптимальна стратегія, сідлова точка, ичіна гри.

\section{Вступ}

Постановка проблеми. Безпека польотів в авіаційній галузі має вирішальне значення. Незважаючи на рекордну кількість пасажирів, статистика показує, що польоти ніколи не були безпечніше. У період з 1959 по 2017 рік було зареєстровано 29298 випадків смертей в результаті 500 авіаційних подій 3 комерційними пасажирськими реактивними літаками. Однак в період з 2008 по 2017 рік в результаті 37 подій загинуло 2199 чоловік, або менше 8\% від загального числа. У 2017 році вперше, принаймні за 60 років існування авіації, на комерційних авіалініях не було смертельних випадків. Навіть 2018 рік, в якому відбулося в цілому 15 смертельних авіакатастроф, займає третє місце з безпеки в історії. Імовірність того, що людина загине в результаті нещасного випадку в комерційній авіації, вкрай мала в порівнянні 3 іншими видами транспорту, наприклад, такими, як автомобільна або велосипедна аварія, а також 3 іншими більш несподіваними сценаріями, такими як випадковий постріл з пістолета або напад собаки [1].

Безперервне підвищення рівня безпеки польотів можна пояснити рядом факторів. Літаки стали більш надійними. Системи безпеки і протоколи значно покращилися. Ряд конструкторських рішень зробив істотний вплив на аварійність, в тому числі удосконалення аеродинамічних характеристик i конструкції лайнера, критеріїв відмовостійкості конструкції, удосконалення приладів кабіни пілотів і збільшення числа експлуатованих літаків 3 автоматично керованим польотом [2].
Наукові досягнення також дозволили авіаційній галузі краще зрозуміти, як людський фактор впливає на безпеку польотів. У той же час були також досягнуті значні поліпшення в виробничих процесах, експлуатації повітряних суден (ПС) та регулюванні [3].

Незважаючи на удосконалення систем управління ПС і повітряним рухом, людський фактор продовжує значно впливати на безпеку польотів [4].

Специфіка діяльності операторів аеронавігаційної системи (АНC), незважаючи на жорстку регламентацію, відрізняється крайньою динамічністю і непередбачуваністю, неможливістю повністю спрогнозувати розвиток подій. Відмінною рисою професійної діяльності операторів АНС є необхідність одночасного виконання двох і більше дій і операцій, спрямованих на вирішення різних завдань (суміщена діяльність) [5], що особливо складно в екстремальних умовах.

У професійній діяльності операторів АНС істотну роль відіграють процеси прийняття рішень. Необхідність вибору варіанту дії, способу його виконання або бажаного результату, особливо в ситуації невизначеності, виникнення непередбачених обставин, висока складність і відповідальність за результат діяльності, зумовлюють високі вимоги, що пред'являються до особистих якостей і здібностей фахівців авіаційного профілю [6].

У звітах про стан безпеки польотів у цивільній авіації держав-учасниць Угоди про цивільну авіацію та про використання повітряного простору [7] наведена статистика, що показує певну динаміку авіаційних подій з вини людського фактору (табл. 1, рис. 1). 
Таблиця 1

Дані звітів з безпеки польотів за 2012-2018 pp.

\begin{tabular}{|c|c|c|c|}
\hline $\begin{array}{c}\text { Звітний } \\
\text { рік }\end{array}$ & $\begin{array}{c}\text { Людсь- } \\
\text { кий фа- } \\
\text { ктор, \% }\end{array}$ & $\begin{array}{c}\text { Відмови та } \\
\text { несправності } \\
\text { авіатехніки, } \\
\%\end{array}$ & $\begin{array}{c}\text { Несприятливі } \\
\text { зовнішні } \\
\text { впливи, \% }\end{array}$ \\
\hline 2012 & 80 & 20 & - \\
\hline 2013 & 83 & 15 & 2 \\
\hline 2014 & 82 & 16 & 2 \\
\hline 2015 & 70 & 24 & 6 \\
\hline 2016 & 94 & 6 & - \\
\hline 2017 & 82 & 17 & - \\
\hline 2018 & 75 & 25 & 2 \\
\hline $\begin{array}{c}\text { В серед- } \\
\text { ньому }\end{array}$ & 81 & 17 & \\
\hline
\end{tabular}

Джерело: розроблено авторами за даними [7].

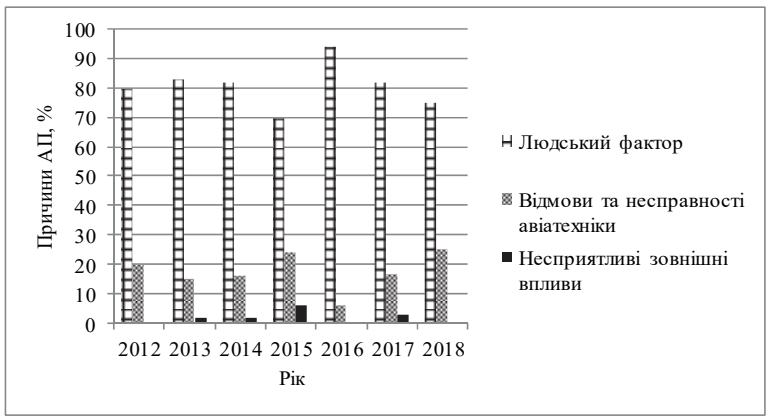

Рис. 1. Графічна інтерпретація даних звітів з безпеки польотів за 2012-2018 pp.

Джерело: розроблено авторами за даними [7].

Як зрозуміло з табл. 1 та рис. 1, в період з 2012 року по 2014 рік показник авіаційних подій з вини людського фактору зберігався на рівні 80-83\%, в 2015 році знизився до 70\%, в 2016 році різко піднявся до 94\%, а в 2017-2018 роках знову пішов на спад.

До числа основних причин авіаційних подій відносять наступні [8]:

- людський фактор - 68\% випадків: 3 них помилки пілота становлять близько $47 \%$ всіх випадків (порушення екіпажем стандартних процедур пілотування; втома, проблеми зі здоров'ям пілотів; помилки екіпажу в складних метеоумовах; помилки в умовах суперечливих показників приладів; дезорієнтація при польоті в незнайомій місцевості; порушення взаємодії між членами екіпажу; недостатня кваліфікація для даного типу ПС); помилки наземних служб - 13\% випадків (помилки авіадиспетчера; неправильна експлуатація, ремонт, обслуговування ПС); терористичні акти - 8\% випадків (захоплення управління, що призводить до падіння ПС; закладка вибухового пристрою в ПС; знищення ПС з земної поверхні);

- відмова техніки - 18\% випадків (старіння; конструктивні недоліки обладнання);

- інші причини - 14\% випадків.
Під час виконання польоту пілот та авіадиспетчер знаходяться у постійній взаємодії, в процесі якої відбувається координація дій, планування сумісної/спільної діяльності, розподіл функцій тощо. В особливих випадках в польоті (ОВП) особливе значення має забезпечення стислості, точності і процедурної сумісності інформаційної взаємодії пілота та авіадиспетчера.

Концептуальна модель, яка використовується авіадиспетчером, і образ польоту пілота - це два види моделей, за допомогою яких авіадиспетчер i пілот здійснюють взаємну професійну діяльність. Зміст цих двох моделей різниться, що обумовлює в ряді випадків нерозуміння між пілотами і авіадиспетчерами, неправильне тлумачення інформації, в кінцевому рахунку приводячи до авіаційної події [9-10].

В ході дослідження помилок, що виникають в процесі взаємодії авіадиспетчерів 3 пілотами, А.І. Онуфраш [11] виділив десять типових видів помилок і визначив частоту їх появи. Найбільш часті помилки - це порушення правил ведення радіообміну (26\%) і суперечлива польотна інформація (22\%). Далі йдуть: неправильні команди (10\%); порушення взаємодії між авіадиспетчерами суміжних зон (8\%); відсутність радіозв'язку (8\%); відсутність радіолокаційного контролю за ПС (6\%); невихід екіпажу на зв'язок при справних радіозасобах (6\%); відсутність доповіді про подію в польоті (6\%); невиконання команд авіадиспетчера (4\%); нечіткі команди авіадиспетчера (4\%) (рис. 2).

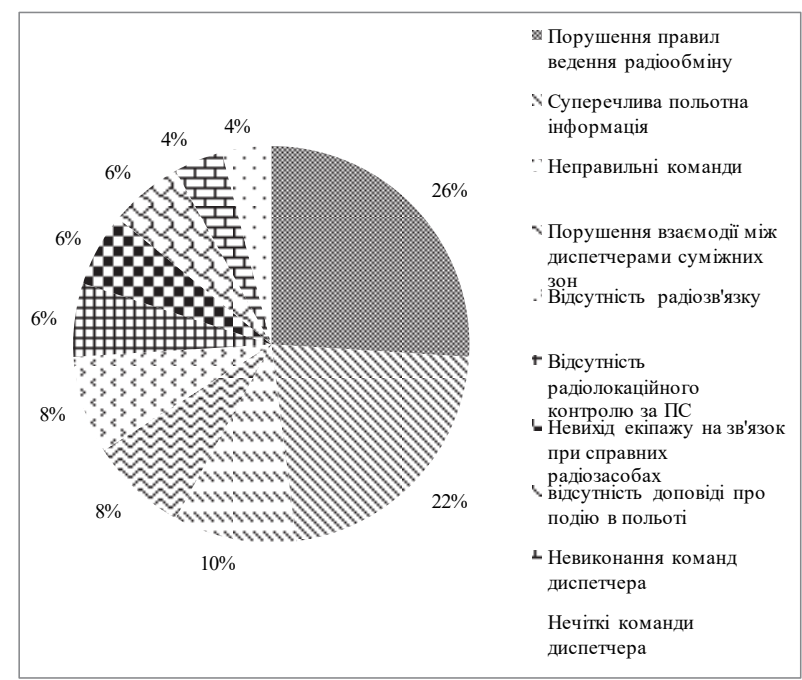

Рис. 2. Розподіл помилок, що виникають в процесі взаємодії авіадиспетчерів з пілотами

Джерело: розроблено авторами за даними [11].

Взаємодію між пілотом та авіадиспетчером можна розглядати як фахово зумовлену, динамічну форму упорядкування активності операторів АНС, що регламентує їх функції й обов'язки та виявляється в цілеспрямованому взаємозв'язку, взаємовпливі, взаєморозумінні й сукупній кооперативній діяльно- 
сті. Взаємодія може здійснюватися у формі сумісного/спільного прийняття рішень (Collaborative Decision Making - CDM) операторами AHC.

CDM операторів AHC грунтується на використанні консолідованої інформації, яка охоплює одержані 3 декількох джерел та системно інтегровані різнотипні інформаційні ресурси, які в сукупності наділені ознаками повноти, цілісності, несуперечності та складають адекватну інформаційну модель проблемної області з метою іiї аналізу, опрацювання та ефективного використання в процесах підтримки прийняття рішень [12].

Впровадження CDM як нового технологічного рішення потребує використання сучасного інформаційного середовища. Відповідно до прийнятого в рамках ICAО Глобального аеронавігаційного плану [13], до 2033 року всі держави - члени організації повинні перейти на загальносистемне управління інформацією (System Wide Information Management - SWIM) [14]. Система SWIM, що об'єднує всі відповідні дані АНС, створить основу для управління інформацією всієї АНС і буде відігравати важливу роль в забезпеченні їі ефективної роботи. Вона буде підтримувати процеси CDM, застосовуючи ефективні програмні додатки для кінцевого користувача, щоб задіяти всю міць спільно використовуваної інформації. В рамках цієї концепції АНС розглядається як серія вузлових пунктів, включаючи всіх зацікавлених сторін на землі і в повітрі, які надають інформацію, що відноситься до них, або використовують іiі. Цей принцип відображений на рис. 3, на якому показані тільки пов'язані з даною мережею учасники, але до неї можуть під'єднатися й інші.

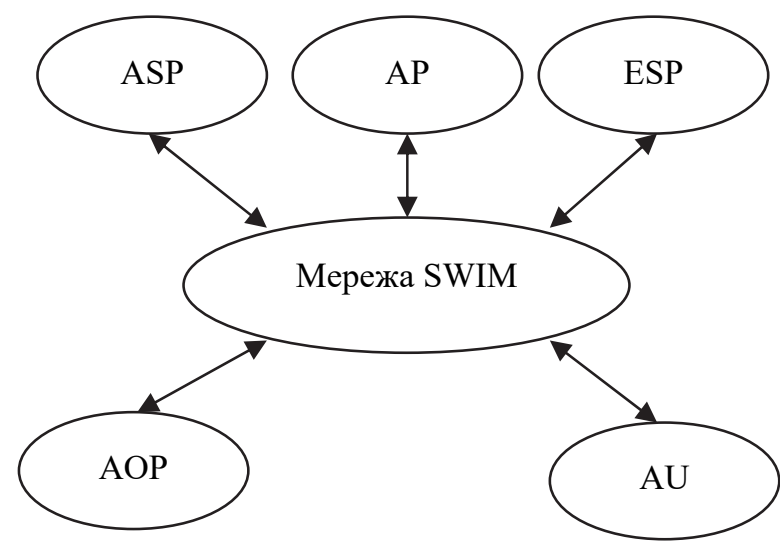

Рис. 3. Логічне представлення мережі SWIM, яка з'єднує учасників АНС Джерело: [15].

На рис. 3: ASP - постачальник аеронавігаційного обслуговування; AP - постачальник повітряного простору; ESP - постачальник аварійного обслуговування; AOP - експлуатант аеродрому; AU - користувач повітряного простору.
Еволюцією нинішнього плану польоту в інформацію і процеси, необхідні для підтримки CDM, є концепція інформації про політ та потоки повітряного руху для сумісного використання повітряного простору (Flight and Flow Information for a Collaborative Environment - FF-ICE) [16]. В рамках FF-ICE буде використовуватися інформація, яка передаватиметься для використання в інших інформаційних областях, таких як аеронавігаційна інформація, метеорологічна інформація та дані спостереження.

Аналіз останніх досліджень і публікацій. Більшість задач, що виникають в АНС на іï різних рівнях та на різних етапах іiі діяльності, вирішується в умовах невизначеності. Ігровий підхід дослідження процесів в умовах невизначеності дає змогу отримувати оптимальні та гарантовані (для найгірших випадків) рішення. Методологічною основою вирішення подібних задач $є$ теорія ігор, предмет дослідження якої - задачі прийняття рішень в умовах невизначеності, що розглядаються насамперед як конфліктні ситуації [17], колективні рішення [18], задачі розроблення оптимальних планів [19].

Ефективність функціонування АНС та забезпечення безпеки польотів насамперед залежать від результатів прийняття індивідуальних та групових рішень [20]. Тому в АНС, в якій оператори приймають рішення у складних ситуаціях, управлінню конфліктами надається велике значення [21]. Правильно керований конфлікт може покращити групові результати рішень [22].

При цьому вирішення конфлікту необхідно провести на обмеженому інтервалі часу, величина якого визначається самою логікою розвитку і перетворення конфліктної ситуації. Хто швидше приймає і виконує правильні рішення, той і виграє. Правильні рішення, але прийняті з запізненням, застарівають, не приносять користі. В цьому аспекті характерні ситуації зі старінням інформації, коли старіюча інформація, яка надходить до оператора, $є$ джерелом конфлікту [23]. Для ілюстрації цього положення можна навести приклади конфліктів, що розглядаються в задачах безпеки повітряного руху, в задачах відходу на запасний аеродром, в задачах усунення затримок у авіаперевезеннях і т.п. Тут довго думати, прострочити час, скористатися застарілою інформацією є програшем, розрішенням конфлікту не в користь того, хто довго думає, тобто, наступає аварія, катастрофа.

Відома модель SHELL (Software, Hardware, Environment, Liveware, Liveware) була першою моделлю для забезпечення безпеки польотів в авіації у процесі безпосереднього аналізу латентних загроз на рівні експлуатаційної взаємодії [24]. Еволюція моделей людського фактору доповнюється відповідними компонентами: помилками оператора, управ- 
лінням помилками, взаємодією операторів у колективі, впливом культури (C - culture) тощо [20]. Відповідно до моделі SHCELL, невідповідність між Liveware та іншими чотирма компонентами сприяє помилкам людини.

У публікаціях [25-28] авторами представлено детерміновані, стохастичні, невизначені та нейромережеві моделі CDM пілотом пілотованого / безпілотного ПС та авіадиспетчером в ОВП для максимальної синхронізації операційних процедур операторів АНС з оптимальними послідовністю дій і часом завершення польоту.

Метою статті $\epsilon$ представити проблему визначення оптимальних стратегій CDM пілотом та авіадиспетчером як задачу розв'язання “конфлікту” між взаємодією Liveware (людина) - Liveware (людина) (L-L). Інтерфейс L-L можна розглянути як CDM пілотом та авіадиспетчером в процесі взаємодії між ними. Наприклад, між пілотом та авіадиспетчером може виникнути конфлікт щодо бажаного ешелону польоту, який необхідно зайняти ПС, але авіадиспетчер не може його звільнити; щодо вибору схеми та режиму заходу на посадку; щодо встановлення радіозв'язку тощо.

\section{Виклад основного матеріалу}

Щоб розв'язати конфліктну ситуацію, що склалася між пілотом та авіадиспетчером в ОВП “Відмова та пожежа двигуна на ПС при наборі висоти після зльоту", і знайти такі оптимальні стратегії операторів, що повинні задовольнити обидві сторони, пропонується математичний аналіз конфлікту за допомогою методів теорії ігор. Для цієї мети будується математична модель конфлікту, що називається грою, а учасники гри - гравцями. У розглядуваному випадку спостерігається некооперативна поведінка ізольованих гравців, коли кожний гравець обирає свою стратегію незалежно, не звертаючи уваги на те, які стратегії обирають інші учасники [29].

Часто теорію ігор називають стратегічною взаємодією раціональних гравців. Стратегічність означає, що гравці думають наперед, як їм діяти, щоб отримати найбільший виграш, а раціональність - що у кожного гравця задана функція, яку він прагне максимізувати [30].

Теорія ігор - це розділ прикладної математики, який надає інструменти для аналізу ситуацій, в яких сторони, так звані гравці, приймають рішення, що $€$ взаємозалежними. Ця взаємозалежність змушує кожного гравця враховувати можливі рішення або стратегіï іншого гравця при формулюванні своєї власної стратегії. Рішення гри описує оптимальні рішення гравців, які можуть мати схожі, протилежні або змішані інтереси, а також результати, які можуть виникнути в результаті цих рішень [31].
Гра - це ідеалізована математична модель колективної поведінки: кілька індивідуумів (учасників, гравців) впливають на ситуацію (результат гри), причому їх інтереси (виграші при різних можливих ситуаціях) різні. Антагонізм інтересів народжує конфлікт, в той час як збіг інтересів зводить гру до чистої координації, для здійснення якої єдиною розумною поведінкою є кооперація [32].

Теорія ігор є корисним логічним апаратом для аналізу поведінки учасників в різних ситуаціях. Вона має арсенал формалізованих сценаріїв поведінки, починаючи з некооперативної поведінки і до коаліційних угод [33].

Гра двох учасників 3 нульовою сумою має вигляд $\left(A_{i}, B_{j}, u_{i j}\right)$, тобто гравці є чистими антагоністами. Для формування матриць гри визначаємо наступні параметри (складові) гри (табл. 2 і табл. 3):

1. Гравець $A$ - пілот (авіадиспетчер) 3 альтернативними рішеннями $-A_{i}$.

2. Гравець $B$ - диспетчер (пілот) 3 альтернативними рішеннями $-B_{j}$.

3. Наслідки $u_{i j}$ - результат взаємодії операторів (пілота, авіадиспетчера).

В термінах теорії ігор маємо, що якщо уявити гру, як $G\left(A_{i}, B_{j}, u_{i j}\right)$, то $u_{i j}\left(A_{i}, B_{j}\right)$ - платіж, який гравець $A$ максимізує, а гравець $B$ мінімізує (табл. 2 і табл. 3).

Таблиця 2

Формальна матрична форма гри “пілот-авіадиспетчер"

\begin{tabular}{|c|c|c|c|c|c|c|}
\hline \multirow{2}{*}{$\begin{array}{c}\text { Стратегії } \\
\text { пілота }\end{array}$} & \multicolumn{6}{|c|}{ Стратегії авіадиспетчера } \\
\cline { 2 - 7 } & $B_{1}$ & $B_{2}$ & $\cdots$ & $B_{j}$ & $\cdots$ & $B_{n}$ \\
\hline$A_{1}$ & $u_{11}$ & $u_{12}$ & $\cdots$ & $u_{1 j}$ & $\cdots$ & $u_{1 n}$ \\
\hline$A_{2}$ & $u_{21}$ & $u_{22}$ & $\cdots$ & $u_{2 j}$ & $\cdots$ & $u_{2 n}$ \\
\hline$\cdots$ & $\cdots$ & $\cdots$ & $\cdots$ & $\cdots$ & $\cdots$ & $\cdots$ \\
\hline$A_{i}$ & $u_{i 1}$ & $u_{i 2}$ & $\cdots$ & $u_{i j}$ & $\cdots$ & $u_{i n}$ \\
\hline$\cdots$ & $\cdots$ & $\cdots$ & $\cdots$ & $\cdots$ & $\cdots$ & $\cdots$ \\
\hline$A_{m}$ & $u_{m 1}$ & $u_{m 2}$ & $\cdots$ & $u_{m j}$ & $\cdots$ & $u_{m n}$ \\
\hline
\end{tabular}

Джерело: розроблено авторами.

Таблиця 3

Формальна матрична форма гри “авіадиспетчер-пілот”

\begin{tabular}{|c|c|c|c|c|c|c|}
\hline \multirow{2}{*}{$\begin{array}{c}\text { Стратегії } \\
\text { aвіадиспет- } \\
\text { чера }\end{array}$} & \multicolumn{7}{|c|}{ Стратегї пілота } \\
\cline { 2 - 7 } & $B_{1}$ & $B_{2}$ & $\cdots$ & $B_{j}$ & $\cdots$ & $B_{n}$ \\
\hline$A_{1}$ & $u_{11}$ & $u_{12}$ & $\cdots$ & $u_{1 j}$ & $\cdots$ & $u_{1 n}$ \\
\hline$A_{2}$ & $u_{21}$ & $u_{22}$ & $\cdots$ & $u_{2 j}$ & $\cdots$ & $u_{2 n}$ \\
\hline$\cdots$ & $\cdots$ & $\cdots$ & $\cdots$ & $\cdots$ & $\cdots$ & $\cdots$ \\
\hline$A_{i}$ & $u_{i 1}$ & $u_{i 2}$ & $\cdots$ & $u_{i j}$ & $\cdots$ & $u_{i n}$ \\
\hline$\cdots$ & $\cdots$ & $\cdots$ & $\cdots$ & $\cdots$ & $\cdots$ & $\cdots$ \\
\hline$A_{m}$ & $u_{m 1}$ & $u_{m 2}$ & $\cdots$ & $u_{m j}$ & $\cdots$ & $u_{m n}$ \\
\hline
\end{tabular}

Джерело: розроблено авторами. 
Тоді обережні стратегії гравців мають вигляд $(1-2)$ :

$$
\begin{aligned}
& A^{*} \in P\left(u_{j}\right) \leftrightarrow \max u_{i j}\left(A_{i,} B_{j}\right)= \\
& =\max \min u_{i j}\left(A_{i}, B_{j}\right) ; \\
& B^{*} \in P\left(u_{i}\right) \leftrightarrow \min u_{i j}\left(A_{i}, B_{j}\right)= \\
& =\min \max u_{i j}\left(A_{i}, B_{j}\right) .
\end{aligned}
$$

Вирази maxmin $u_{i j}$ і $\operatorname{minmax~} u_{i j} \quad \epsilon$ відповідно максимальним гарантованим виграшем гравця $A$ i мінімальним гарантованим програшем гравця $B$.

Якщо виконується рівність (3):

$$
\begin{aligned}
& v=\max \min u_{i j}\left(A_{i}, B_{j}\right)= \\
& =\min \max u_{i j}\left(A_{i}, B_{j}\right),
\end{aligned}
$$

тоді $v \in$ ціною гри $G$.

Якщо гра двох осіб $G\left(A_{i}, B_{j}, u_{i j}\right)$ з нульовою сумою має ціну гри, то вона неістотна, тобто, розв'язується конфлікт. Оптимальні стратегії визначаються ізольовано (як обережні стратегії) або одночасно двома гравцями (як сідлові пари).

На рис. 4 представлена поверхня, що має сідловидну форму, де точка $K$ - сідлова точка гри, яка $\epsilon$ точкою перетину оптимальних стратегій гравців 3 табл. 3 - $A$ (авіадиспетчера) і $B$ (пілота).

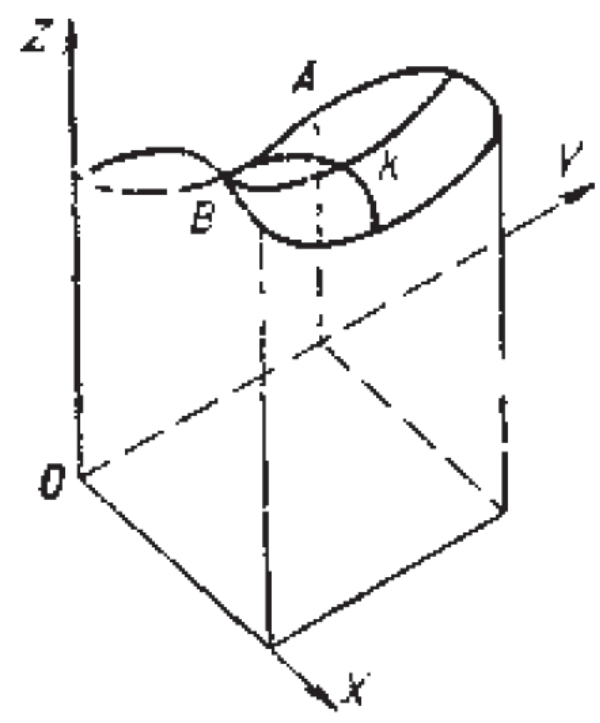

Рис. 4. Геометрична інтерпретація гри “авіадиспетчер-пілот" Джерело: [19, С. 669].

Визначимо оптимальні стратегії як сідлові пари для двох гравців і розглянемо антагоністичну парну гру 3 нульовою сумою, де гравцями виступають оператори АНС (пілот та диспетчер, що здійснюють взаємну професійну діяльність), і виграш авіадиспетчера дорівнює програшу пілота (наприклад, відповідно до табл. 3).
Під виграшем (програшем) гравців у загальному випадку розуміється приріст корисності [34], одержимо такі закономірності поведінки гравців (пілота і авіадиспетчера):

- авіадиспетчер прагне в найгіршій для себе поведінці пілота отримати максимальний виграш;

- пілот прагне в найгіршій для себе поведінці авіадиспетчера отримати мінімальний програш.

Визначимо стратегії першого гравця $A$ (авіадиспетчера), виходячи 3 факторів, які впливають на прийняття ним рішень в ОВП “Відмова та пожежа двигуна на ПС при наборі висоти після зльоту”:

- зв'язок з екіпажем ПС, $\lambda_{11}$;

- наявність безпілотних ПС, $\lambda_{12}$;

- завантаженість зони управління повітряним рухом, $\lambda_{13}$.

Відповідно пілот (гравець $B$ ) має стратегії щодо завершення польоту в залежності від наступних факторів:

- віддаленості ПС від місця посадки, $\lambda_{21}$;

- наявності палива, $\lambda_{22}$;

- характеристик місця посадки, $\lambda_{23}$;

- режиму заходу на посадку, $\lambda_{24}$ тощо.

Для визначення результатів (виграшів) вибору стратегій було проведено анкетування групи авіаційних фахівців (пілотів, авіадиспетчерів), на підставі чого сформовано дві матриці: оцінки експертів у випадку вимушеної посадки зі зворотним курсом (табл. 4) та вимушеної посадки 3 прямим курсом (табл. 5).

Елементи матриць визначались за 5-бальною номінальною шкалою від 1 до 5 , де 1 - найгірший результат, 5 - найкращий.

Методом експертних оцінок отримано узгоджені дані, достовірність яких підтверджено результатами статистичної обробки (коефіцієнти варіації не перевищують $33 \%$, доведено статистичну значущість за критеріями Стьюдента та $\chi^{2}$ ). Розрахунки проведено за допомогою MS Excel [35].

В обох випадках верхня ціна гри $(\beta)$, більше від якої за певної стратегії пілот не програє, і нижня ціна гри $(\alpha)$, менше від якої за певної стратегії авіадиспетчер не виграє, збігається.

Для вимушеної посадки зі зворотним курсом (табл. 4) маємо ціну гри:

$$
\begin{aligned}
& v=\max \min u_{i j}\left(B_{j}\right)=\alpha= \\
& =\min \max u_{i j}\left(A_{i}\right)=\beta=2,
\end{aligned}
$$

Для вимушеної посадки 3 прямим курсом (табл. 5) ціна гри:

$$
\begin{aligned}
& v=\max \min u_{i j}\left(B_{j}\right)=\alpha= \\
& =\min \max u_{i j}\left(A_{i}\right)=\beta=3,
\end{aligned}
$$


Оцінки експертів у випадку вимушеної посадки зі зворотним курсом

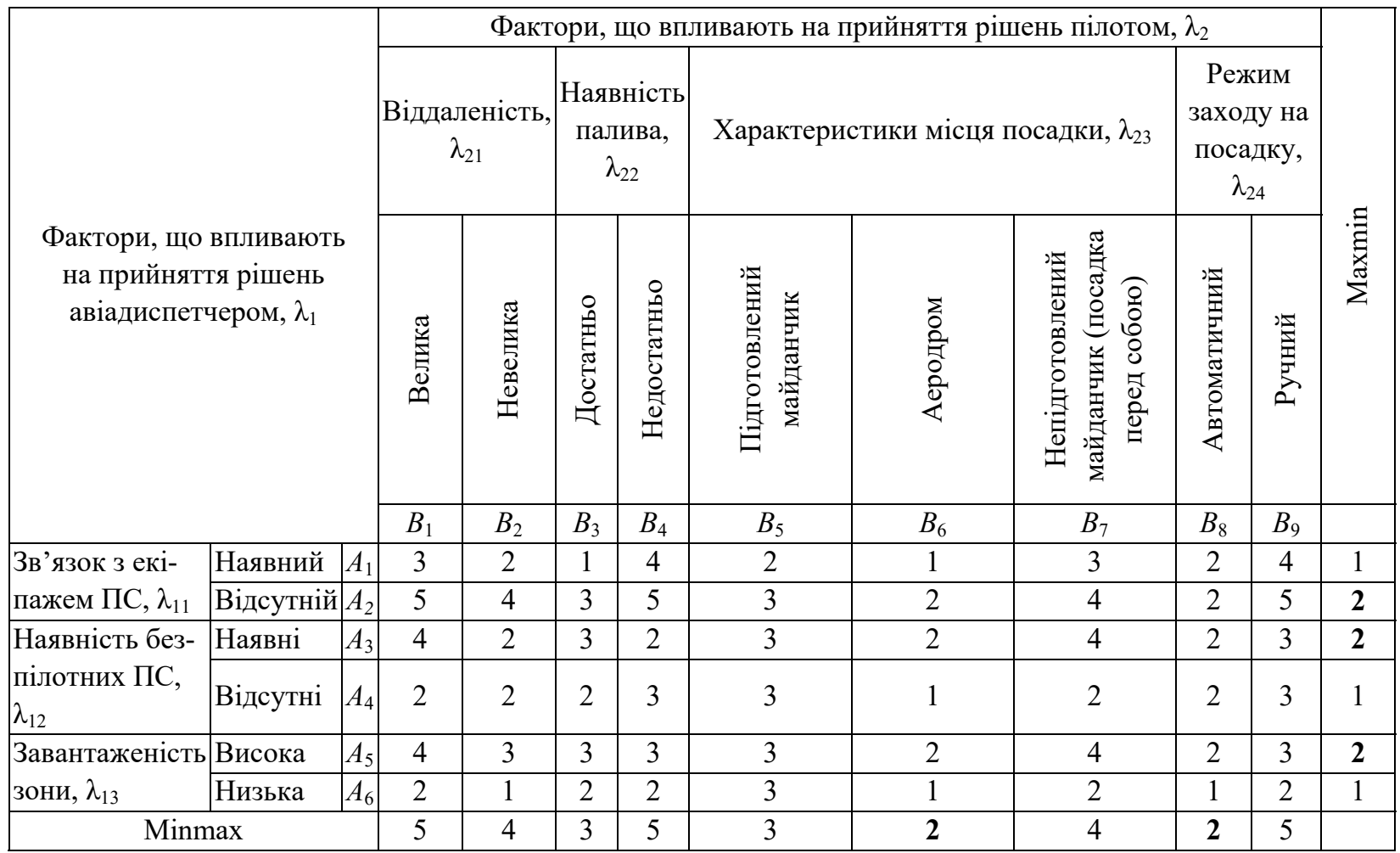

Джерело: розроблено авторами.

Таблиця 5

Оцінки експертів у випадку вимушеної посадки з прямим курсом

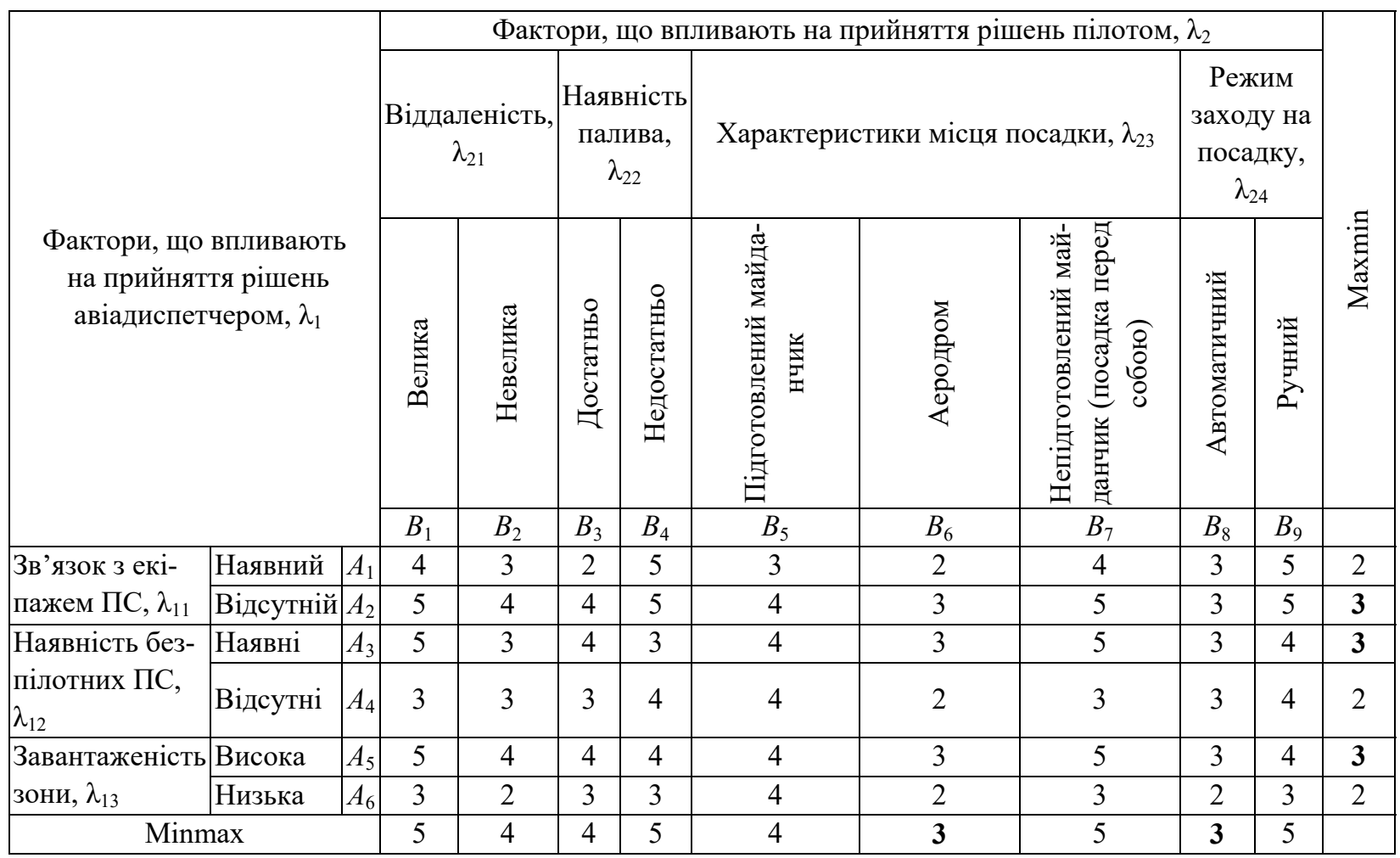

Джерело: розроблено авторами.

Оптимальні стратегії першого гравця (авіадиспетчера), в яких він повинен максимально проявити свої професійні здібності та продемонструвати готовність до дій в аварійних ситуаціях, як для вимуше- 
ної посадки зі зворотним, так і з прямим курсом:

- відсутність зв'язку з екіпажем ПС $\left(A_{2}\right)$;

- наявність безпілотних ПС $\left(A_{3}\right)$;

- висока завантаженість зони управління повітряним рухом $\left(A_{5}\right)$.

Для другого гравця (пілота) оптимальною стратегією є посадка в автоматичному режимі $\left(B_{8}\right)$ на аеродромі $\left(B_{6}\right)$, на якому $є$ придатна для використання злітно-посадкова полоса та функціонують радіотехнічні засоби посадки.

Одержані сідлові точки матриць $v=2$ та $v=3$ забезпечуються оптимальними стратегіями гравців i ведуть до розв'язання конфлікту 3 мінімальними витратами.

Аналогічні розрахунки проведено для матричної гри “пілот-авіадиспетчер”, представленої в табл. 2, де пілот прагне в найгіршій для себе поведінці авіадиспетчера отримати максимальний виграш, а авіадиспетчер прагне в найгіршій для себе поведінці пілота отримати мінімальний програш [20].

\section{Висновки}

Методологічною основою вирішення задачі визначення оптимальних стратегій CDM пілотом та авіадиспетчером в умовах невизначеності $€$ теорія ігор, яка розглядає взаємодію між операторами АНC, насамперед, як конфліктну ситуацію.
Застосування методів теорії ігор на прикладі ОВП “Відмова та пожежа двигуна на ПС при наборі висоти після зльоту” показало, що за відсутності зв'язку авіадиспетчера 3 екіпажем ПС, наявності безпілотних ПС та високій завантаженості зони управління повітряним рухом оптимальною стратегією пілота є посадка в автоматичному режимі на аеродромі з підготовленою злітно-посадковою смугою, обладнаному радіотехнічними засобами посадки.

В наступних дослідженнях передбачається визначити оптимальні колаборативні/сумісні рішення (CDM) операторів АНC в конкретній польотній ситуації за допомогою критеріїв прийняття рішень в умовах невизначеності: Вальда, Лапласа, Гурвиця, Севіджа. Матриця рішень формується альтернативними рішеннями, які приймають оператори АНС (стратегії гравця $A$ ), факторами, що впливають на прийняття рішення (гравець $B$ ), та результатами рішень. До формування множини факторів застосовується об'єктивно-суб'єктивний підхід, де об'єктивні фактори залежать від польотної ситуації, що склалась, а суб'єктивні фактори - від прийняття рішень операторами АНС, які приймають участь в розрішенні ситуації.

\section{Список літератури}

1. Aviation Risk 2020. Safety and the State of the Nation. - Allianz Global Corporate \& Specialty SE, 2019. -28 p.

2. Stanton N.A. Ergonomics and Human Factors in Aviation / N.A. Stanton, W.-Ch. Li, D. Harris // Ergonomics. - 2019. Vol. 62. - Is. 2. - P. 131-137. https://doi.org/10.1080/00140139.2019.1564589.

3. Human Factors in Aviation / Eds. E. Salas, D. Maurino. - 2nd ed. - USA, Cambridge, Massachusetts: Academic Press, 2010. - 744 p. https://doi.org/10.1016/C2009-0-01731-0.

4. Handbook of Aviation Human Factors / Eds. J.A. Wise, V.D. Hopkin, D.J. Garland. - 2ed ed. - USA, Florida: CRC Press, 2016. - 704 p. https://doi.org/10.1201/b10401.

5. Jensen R.S. The Boundaries of Aviation Psychology, Human Factors, Aeronautical Decision Making, Situation Awareness, and Crew Resource Management / R.S. Jensen // The International Journal of Aviation Psychology. - 1997. - Vol. 7. Iss. 4. - P. 259-267. https://doi.org/10.1207/s15327108ijap0704_1.

6. Johnston N. Aviation Psychology in Practice / N. Johnston, N. McDonald. - 1st ed. - G.B., London: Routledge, 1997. 390 p. https://doi.org/10.4324/9781351218825.

7. Официальный сайт Межгосударственного авиационного комитета (МАК). Отчеты о состоянии безопасности полетов. - Режим доступа: https://www.mak-iac.org/rassledovaniya/bezopasnost-poletov/.

8. Официальный сайт РИА НОВОСТИ Россия. Основные причины авиакатастроф. - Режим доступа: http://www.inosmi.ru/infographic/20120703/194443129.html 03.07.2012.

9. Булава В.В. До питання професійної надійності пілотів цивільної авіації / В.В. Булава // Науковий вісник Льотної академії. Серія: педагогічні науки. - 2019. - Вип. 6. - С. 27-35. https://doi.org/10.33251/2522-1477-2019-6-27-35.

10. Невзоров Р.В. Методика тренажерної підготовки курсантів-льотчиків в умовах вищих військових навчальних закладів до виконання бойових завдань / Р.В. Невзоров // ScienceRise: Pedagogical Education. - 2017. - № 4(12). C. 14-19. https://doi.org/10.15587/2519-4984.2017.100174.

11. Онуфраш А.И. Медицинский анализ ошибочных действий и нарушений лётного состава и разработка рекомендаций по их профилактике: заключительный отчёт о НИР с рекомендациями (№ государственной регистрации 79049703, инвентарный № Б 965985, 9 июля 1981 г) / руководитель работы и ответственный исполнитель А.И. Онуфраш. - М.: ГосНИИ ГА, 1981. $-55 \mathrm{c}$.

12. Pylypenko A. Effectiveness evaluation of search ininformation systems with consolidated information / A. Pylypenko, A. Popov // Radio Electronics, Computer Science, Control. - 2017. - № 2. - P. 103-109. https://doi.org/ 10.15587/17294061.2017.108929.

13. Чехов И.А. Пути развития систем навигации в рамках внедрения концепции CNS/ATM / И.А. Чехов // Научный Вестник МГТУ ГА. - 2017. - Т. 20. - № 04. - 142 c. https://doi.org/10.26467/2079-0619-2017-20-4-98-106.

14. Lu X. Real-Time Oriented System Wide Information Management for Service Assurance / X. Lu, T. Koga // 2015 IEEE Twelfth International Symposium on Autonomous Decentralized Systems: Proceedings. - Taichung, Taiwan, 25-27 March, 2015. - P. 175-180. https://doi.org/10.1109/ISADS.2015.22. 
15. Manual on Flight and Flow Information for a Collaborative Environment (FF-ICE). - Doc. 9965. - 1st ed. - Canada, Montreal: ICAO, 2012. - 140 p.]

16. The Manual Airport CDM Implementation. - Brussels, Belgium: European Organization for the Safety of Air Navigation, 2012. $-359 \mathrm{p}$.

17. Alper S. Conflict management, efficacy, and performance in organizational teams / S. Alper, D. Tjosvold, K.S. Law // Personnel Psychology. - 2000. - No. 53(3). - P. 625-642. https://doi.org/10.1111/j.1744-6570.2000.tb00216.x.

18. Peterson M. An Introduction to Decision Theory (Cambridge Introductions to Philosophy) / M. Peterson. - 1st ed. GB, Cambridge: Cambridge University Press, 2009. - 328 p. https://doi.org/10.1017/CBO9780511800917.

19. Кононюк А.Е. Основы теории оптимизации / А.Е. Кононюк. - Кн. 1. - К.: Освіта України, 2011. - 692 с.

20. Socio-Technical Decision Support in Air Navigation Systems: Emerging Research and Opportunities: manuscript / Eds. T. Shmelova, Yu. Sikirda, N. Rizun, A.-B. M. Salem, Yu. Kovalyov. - USA, Hershey: IGI Global, 2018. - 305 p. https://doi.org/10.4018/978-1-5225-3108-1.

21. Harris D. Aviation as a System of Systems: Preface to the Special Issue of Human Factors in Aviation / D. Harris, N.A. Stanton // Ergonomics. - 2010. - Vol. 53(2). - P. 145-148. https://doi.org/10.1080/00140130903521587.

22. Kuhn T. Do conflict management styles affect group decision making? / T. Kuhn, M.S. Poole // Human Communication Research. - 2000. - No. 26(4). - P. 558-590. https://doi.org/10.1111/j.1468-2958.2000.tb00769.x.

23. Johnston N. Aviation Psychology in Practice / N. Johnston, N. McDonald. - 1st ed. - G.B., London: Routledge, 1997. 390 p. https://doi.org/10.4324/9781351218825.

24. Training Flight Accidents. An Explorative Analysis of Influencing Factors and Accident Severity / S.Y. Lee, P. Bates, P. Murray, W. Martin // Aviation Psychology and Applied Human Factors. - 2017. - No. 7. - P. 107-113. https://doi.org/10.1027/2192-0923/a000121.

25. Моделювання консолідованого прийняття рішень екіпажем та диспетчером в особливих випадках в польоті / М.В. Касаткін, Ю.В. Сікірда, Т.Ф. Шмельова, П.В. Гризодуб // Наука і техніка Збройних Сил Повітряних Сил України. 2019. - № 1(34). - C. 30-38. https://doi.org/10.30748/nitps.2019.34.04.

26. Kasatkin M. Network Analysis of Collaborative Decision Making by Air Navigation System's Human-Operators during Emergency Cases in Flight / M. Kasatkin, Yu. Sikirda, T. Shmelova // Proceedings of the National Aviation University. - 2019. No. 1(78). - P. 22-35. https://doi.org/10.18372/2306-1472.1.13652.

27. Шмельова Т.Ф. Детерміновані та недетерміновані моделі сумісного прийняття рішень операторами аеронавігаційної системи / Т.Ф. Шмельова, Ю.В. Сікірда, М.В. Касаткін // Наука і техніка Збройних Сил Повітряних Сил України. - 2020. - Вип. 1(38). - С. 91-99. https://doi.org/10.30748/nitps.2020.38.11.

28. Shmelova T. Modeling of the Collaborative Decision Making by Remote Pilot and Air Traffic Controller in Flight Emergencies / T. Shmelova, Yu. Sikirda, M. Kasatkin // Actual Problems of Unmanned Aerial Vehicles Developments (APUAVD-2019): IEEE 5th International Conference, Kyiv, Oct. 22-24, 2019: Proceedings. - K.: National Aviation University, 2019. - P. 230-233. https://doi.org/10.1109/APUAVD47061.2019.8943877.

29. Cavagnetto S. Game Theory - Its Applications to Ethical Decision Making / S. Cavagnetto, B. Gahir // CRIS Bulletin. 2014. - No. 1. - P. 73-91. https://doi.org/10.2478/cris-2014-0005.

30. Yoshida W. Game Theory of Mind [Electronic resource] / W. Yoshida, R. J. Dolan, K. J. Friston // PLoS Comput Biol. - 2008. - No. 4(12). - Available at: https:/journals.plos.org/ploscompbiol/article?id=10.1371/journal.pcbi.1000254. https://doi.org/10.1371/journal.pcbi.1000254.

31. Schelling T.C. A Game Theory: A Practitioner's Approach / T.C. Schelling // Economics \& Philosophy. - 2010. Vol. 26. - Iss. 1. - P. 27-46. https://doi.org/10.1017/S0266267110000040.

32. Tadelis S. Game Theory: An Introduction / S. Tadelis. - 1st ed. - USA, Princeton: Princeton University Press, 2013. 396 p. https://doi.org/10.1111/1475-4932.12156.

33. Самуэльсон Л. Теория игр в экономической науке и не только / Л. Самуэльсон // Вопросы экономики. - 2017. № 5. - C. 89-115. https://doi.org/10.32609/0042-8736-2017-5-89-115.

34. Peterson M. An Introduction to Decision Theory (Cambridge Introductions to Philosophy) / M. Peterson. - 2nd ed. -

USA, Cambridge: Cambridge University Press, 2017. - 348 p. https://doi.org/10.1017/CBO9780511800917.

35. Shmelova T. Stochastic Methods for Estimation and Problem-Solving in Engineering: Stochastic Methods of Decision Making in Aviation / T. Shmelova // In Stochastic Methods for Estimation and Problem Solving in Engineering / Ed. S. Kadry. USA, Hershey: IGI Global, 2018. - P.139-160. https://doi.org/ 10.4018/978-1-5225-5045-7.ch006.

Надійшла до редколегії 09.09.2020 Схвалена до друку 13.10.2020

\section{Відомості про авторів:}

\section{Сікірда Юлія Володимирівна} кандидат технічних наук доцент доцент Льотної академії Національного авіаційного університету, Кропивницький, Україна https://orcid.org/0000-0002-7303-0441

\section{Шмельова Тетяна Федорівна}

доктор технічних наук доцент

професор Національного авіаційного університету, Київ, Україна

https://orcid.org/0000-0002-9737-6906

\section{Information about the authors:}

\section{Yuliya Sikirda}

Candidate of Technical Sciences Associated Professor

Senior Lecturer of Flight Academy

of the National Aviation University,

Kropyvnytskyi, Ukraine

https://orcid.org/0000-0002-7303-0441

\section{Tetiana Shmelova}

Doctor of Technical Sciences Associated Professor

Professor of National Aviation University,

Kyiv, Ukraine

https://orcid.org/0000-0002-9737-6906 


\section{Касаткін Микола Володимирович}

здобувач наукового ступеня кандидата технічних наук начальник навчально-тренувального комплексу факультету перепідготовки та підвищення кваліфікації авіаційного персоналу Харківського національного університету Повітряних Сил ім. І. Кожедуба, Миколаїв, Україна https://orcid.org/0000-0002-2501-1756

\section{Тригуб Юрій Ігорович}

викладач

Харківського національного університету

Повітряних Сил ім. І. Кожедуба,

Харків, Україна

https://orcid.org/0000-0001-6785-0286

\section{Mykola Kasatkin}

Doctoral Student

Head of Simulator Department of Faculty

of Aviation Personnel Retraining

and Advanced Training

of Ivan Kozhedub Kharkiv National Air Force University,

Mukolaiv, Ukraine

https://orcid.org/0000-0002-2501-1756

\section{Yurii Trigub}

Instructor

of Ivan Kozhedub

Kharkiv National Air Force University,

Kharkiv, Ukraine

https://orcid.org/0000-0001-6785-0286

\title{
ОПТИМИЗАЦИЯ СТРАТЕГИЙ СОВМЕСТНОГО ПРИНЯТИЯ РЕШЕНИЙ ОПЕРАТОРАМИ АЭРОНАВИГАЦИОННОЙ СИСТЕМЫ В КОНФЛИКТНЫХ СИТУАЦИЯХ
}

\author{
Ю.В. Сикирда, Т.Ф. Шмелева, Н.В. Касаткин, Ю.И. Тригуб
}

В статье представлена проблема определения оптимальных стратегий совместного принятия решений пилотом и авиадиспетчером как задача решения “конфликта" между ними методами теории игр. Приведен пример модели конфликтной ситуачии "пилот - авиадиспетчер" в особом случае в полете "Отказ и пожар двигателя на воздушном судне при наборе высоты после взлета”. Показано, что в аварийной ситуачии при отсутствии связи авиадиспетчера с экипажем воздушного судна, наличии беспилотных воздушных судов и высокой загруженности зоны управления воздушным движением оптимальной стратегией пилота является посадка в автоматическом режиме на аэродроме с подготовленной взлетно-посадочной полосой, оборудованном радиотехническими средствами посадки.

Ключевые слова: игроки, критерий Вальда, матричная форма, модель конфликта, оптимальная стратегия, седловая точка, цена игры.

\section{OPTIMIZATION OF THE STRATEGIES OF COLLABORATIVE DECISION MAKING BY OPERATORS OF THE AIR NAVIGATION SYSTEM IN THE CONFLICT SITUATIONS}

\author{
Yu. Sikirda, T. Shmelova, M. Kasatkin, Yu. Trigub
}

Despite the record number of passengers, statistics show that flights have never been safe. Security systems and protocols have improved significantly. A number of design decisions have had a significant impact on accidents, including improvements in the aerodynamic characteristics, failure criteria, improvement of cockpit instruments and an increase in the number of operated aircraft with automatically controlled flight. Despite the improvement of aircraft and air traffic control systems, the human factor continues to have a significant impact on flight safety. During the flight, the pilot and the air traffic controller are in constant interaction, in the process of which there is coordination of actions, planning of joint activities, division of functions, etc. During emergency cases in flight it is of special importance to ensure the brevity, accuracy and procedural compatibility of the information interaction between the pilot and the air traffic controller. In this article, the problem of determining the optimal strategies of collaborative decision making by the pilot and air traffic controller as a task of resolving the "conflict" between them by the methods of game theory is presented. An example of the model of conflict situation "pilot - air traffic controller" in flight emergency "Engine failure and fire on aircraft during climbing after take-off" is given. For this purpose, a mathematical model of conflict is built, called a game, and the participants in the game - the players. In this case, there is a non-cooperative behavior of isolated players, when each player chooses his strategy independently, regardless of which strategies are chosen by other participants. It is shown that in an emergency in the absence of communication between the air traffic controller and the aircraft crew, the presence of unmanned aircraft and high load of the air traffic control zone, the optimal strategy of the pilot is automatically landing at the aerodrome with a prepared runway and landing radio means.

Keywords: conflict model, matrix form, game price, optimal strategy, players, saddle point, Wald criterion. 